\title{
Spirituality in the Healthcare Workplace
}

\author{
Donia Baldacchino $1,2,3,+$
}

1 Faculty of Health Sciences, University of Malta, MSD 2090 Msida, Malta; donia.baldacchino@um.edu.mt; Tel.: +356-2340-1847

2 Department of Nursing, University of South Wales, Pontypridd CF37 4BE, UK

3 Department of Nursing, Johns Hopkins University, Baltimore, MD 21218, USA

+ The author has passed away.

In memoriam

Professor Donia Baldacchino was a global leader in the field of Spirituality and Health in nursing. She was deeply committed to integrating spiritual care in nursing education and care. Her research as well as her pastoral insights contributed significantly to the global recognition of the role of spiritual care in nursing care. She supervised numerous PhD Nursing students in her country in Malta and in many other countries. Her passion for this field lives on in the lives of students, colleagues and friends all over the world who have been deeply touched by her presence and scholarship.

Received: 23 June 2017; Accepted: 30 October 2017; Published: 28 November 2017

\begin{abstract}
Spirituality involves a sense of connectedness, meaning making and transcendence. There is abundant published research that focuses on the importance of spirituality to patients and their families during times of illness and distress. However over the last decade there has also been a growing awareness about the importance of considering the need to address peoples' spiritual needs in the workplace. Engaging in ones own personal spirituality involves connecting with the inner self, becoming more self aware of ones humanity and limitations. Engaging with ones personal spirituality can also mean that people begin to greater find meaning and purpose in life and at work. This may be demonstrated in the workplace by collegial relationships and teamwork. Those who engage with their own spirituality also engage more easily with others through a connectedness with other staff and by aligning their values with the respective organization if they fit well with ones personal values. Workplace spirituality is oriented towards self-awareness of an inner life which gives meaning, purpose and nourishment to the employees' dynamic relationships at the workplace and is eventually also nourished by meaningful work. Exercising ones personal spirituality contributes towards generating workplace spirituality. Essentially acting from ones own personal spirituality framework by being in doing can contribute towards a person becoming a healing and therapeutic presence for others, that is nourishing in many workplaces. Personal spirituality in healthcare can be enhanced by: reflection in and on action; role-modeling; taking initiative for active presence in care; committing oneself to the spiritual dimension of care; and, integrating spirituality in health caregivers' education. As spirituality is recognized as becoming increasingly important for patients in healthcare, increasing educational opportunities are now becoming available for nurses internationally that could support personal and workplace spirituality.
\end{abstract}

Keywords: workplace spirituality; nurse; caregivers; patients

\section{Introduction}

In recent decades, there has been an increasing body of literature that focuses on the importance of spirituality at the workplace (Liu and Robertson 2011; Nash and Stevenson 2004). Research demonstrates that supporting workplace spirituality in the business sector, for example, generates increased productivity, higher teamwork, and greater profits (Overell 2002). Also, there is a positive association between the workplace spirituality and employee job outcomes (Pfeffer 2003). Spirituality 
involves finding meaning and purpose in life, connectedness with others and demonstrating core values related to these concepts (World Health Organisation 1998).

Aim

The aim of this discussion paper is to explore the importance and potential contribution of spirituality to the healthcare workplace. This discussion is contextualized and framed within the Theoretical Framework of Spirituality at the Workplace (Milliman et al. 2003).

\section{Defining 'Spirituality at the Workplace'}

It is considered that the individual's spirit is a person's animating principle, the life force, which motivates an individual to find meaning, purpose, and value, or a sense of worth in life. Spirituality applies equally to the workplace. The consideration of spirituality in relation to healthcare workplace is of particular interest as not only is spiritual meaning useful for nurses there is potential therapeutic benefit for patients and families, where strong spiritual values exist. It is important to note that being spiritual does not necessarily mean expressing religious views, but rather refers to a set of beliefs that place high value finding personal meaning in life events, transcendence, and connection to others. The framework for exploring or understanding this can be either non-religious or religious. It is apt to consider spirituality in healthcare as nurses devote a great deal of their working life interacting closely with others (Roger 2014). Although spirituality is acknowledged in the literature as a personal issue, definitions of workplace spirituality extend this principle towards seeking spiritual connectedness at work; by enhancing deeper values and wholeness (Gibbons 2015). In health care, workplace spirituality incorporates one's efforts to find meaning and purpose in life; maintain healthy relationships with the members of the multidisciplinary team, relatives, and other workers; and, the maintenance of a coherence between one's core beliefs and the values of the respective organization (Neal 2013). In the workplace value comes from work when one believes that one is making a contribution, making a difference, and connecting to others and to something beyond, and greater than oneself, through pursuing a common purpose (Solutions 2015). It is easy to understand that personal spirituality can align nicely within the healthcare context as many of these latter concepts can be intrinsic components of caring for others. Workplace spirituality may be summarized as: 'the recognition that employees have an inner life that nourishes and is nourished by meaningful work that takes place in the context of the community' (Ashmos and Duchon 2000). The need to find meaning is universal, therefore, spirituality, whether it is religious or not, can impact ones professional life. Personal spirituality may or may not incorporate religion (Baldacchino and Draper 2001). However, the beliefs of those people who hold particular religious beliefs may animate and enrich their work, and is it no surprise that a great deal of healthcare organizations internationally had religious Christian origins. The Christian religious perspective of spirituality is oriented towards a vision of the common good, community spirit, and compassion, whereby there is an awareness of one's relationship to others. Although religious organizations are less involved than in the past, some organizations retain these Christian values as their core values, that is, the staff members and the patients and their relatives; sensitivity to the sufferings of others, and ensure a quality presence which fosters being with and being there (Roach 2002). As such religious beliefs have in the past strengthened caring values and enhance contribution to others. Forgiveness is another important example of a Christian value that can be useful in the workplace. Forgiveness of colleagues, when necessary for example, may strengthen personal resilience at work (Adamson et al. 2012; Koutsos et al. 2008). This may also be therapeutic in strengthening relationships and teamwork. This may be achieved through self-transcendence, whereby the individual may go beyond oneself to reach a higher power with resultant empowerment to maintain peaceful teamwork and relationships with colleagues at work (Levenson et al. 2006; Frankl 1966). However it must be remembered that while these may be deemed as important [spiritual] values not all nurses work in organisations that hold such values nor do they necessarily work with staff from Christian backgrounds. Indeed, even when working with co-workers who claim Christian 
spirituality differences can emerge in interpretation and application with arising conflicts around deadlines, decision-making process and ethical issues for example. This can be compounded by workplace stress and problems with management and interpersonal relationships. What is most important, and where developing workplace spirituality can make a difference is [regardless of shared beliefs] developing a safe environment where staff trust one another, communicate openly, develop relationships, and work together to find shared meaning and purpose. In the workplace it is important that the team is united, as each individual's effort to strengthen teamwork and maintain workplace spirituality contributes to overall harmony and needs to be appreciated. Therefore, it is my view that it is important for each nurse to reflect on their own spirituality and live a meaningful life in order to support their colleagues and also to help patients and families by therapeutically helping them to find meaning and purpose in their illness or experiences. Indeed the first step in addressing patients' spiritual needs and providing spiritual care is being aware of ones own spirituality and personal beliefs. For some nurses continuous self-awareness and connectedness with a dimension beyond the self for inner resource can yield to personal growth and wholeness. This in turn, may support the delivery of spiritual care (Chung et al. 2007). However further research is required to explore this concept further, especially on the transcendent dimension of workplace spirituality to explore its possible contribution towards finding meaning and purpose at the workplace Particular emphasis is needed on researching the importance of spirituality on psychosocial dimensions of interactions within the workplace and thepotential influence on patients' spirituality (Tanyi 2002; Robinson and Kendrick 2000). Supporting patients' spirituality enables them to find meaning and purpose during life's challenges and nurses are well placed to support them to find this meaning (Baldacchino 2011, 2015; Montebello 2010; Prince-Paul 2008).

Workplace spirituality must also consider the perspective that employees have their own spiritual needs, just as they have the physical, emotional, and cognitive needs (Duchon and Plowman 2005). For some, these spiritual needs are also religious (Torskenes et al. 2013). Thus, it is important for many faith groups to have a sacred space in the workplace to provide comfort and privacy during prayer. Even though traditional churches are less commonly a feature of modern hospital life, many new builds, especially in palliative care settings, incorporate this sacred space. While this may seem somewhat out of place in a modern world, research demonstrates that work environments that foster a sense of community and enable a sense of meaningful work, perform better than those that are less attentive to the need of the spirit (Mitroff and Denton 1999). When nurses manage to find meaning and purpose at work, apart from the financial gains derived from their work, they seek something which goes far beyond material rewards, such as, peacefulness and spiritual growth through giving and receiving, whereby caregivers do not only provide spirituality at work, but also they are spiritually satisfied by their meaningful work (Baldacchino 2010a).

Living in a community as spiritual beings demands the need of belongingness to that respective group, which may generate a connectedness to one another by sensitivity to each other's needs; forgiveness to restore and maintain relationships; and, a supportive attitude to each other. The over-arching connection is the leader of the group who manages to create a vision for the future and motivates others to be part of this vision (Fry 2003), with resultant high sense of community and therapeutic relationships:

"People thrive in a community and function best when they share praise, comfort, happiness, and humour with people they like and respect... This kind of social support reaffirms a person's membership in a group with a shared sense of values". (Maslach and Leiter 1997)

Research has consistently found that enhancing spirituality at the workplace is beneficial for both staff and patients (Daniel 2012; McKee et al. 2011; Sadeghifar et al. 2013). The Theory of Spirituality in the Workplace will now be discussed as it serves to elucidate and explain these findings and their value. 


\section{The Theory of Spirituality in the Workplace}

This theory consists of the relationship of the individual person at the workplace with the following three core dimensions of spirituality at the workplace namely: Purpose in one's work or 'meaningful work' at an individual level; a sense of community at a group level; and, alignment with the organization's values and mission at the organization level.

\subsection{Meaningful Work}

The essence of spirituality at work involves having a deep sense of meaning and purpose in one's work', which enables the individual employee to interact harmoniously with one's daily work. According to Frankl (Frankl 1973) when one has a WHY for living, eventually he/she will live with ANY HOW. The individual expresses his/her own spirituality at work through his/her own inner motivations, truths, and wishes to be involved in activities that enhance meaning to his/her personal life and the lives of others. Thus, meaningful work is not only associated with the quest for personal purpose but also with altruistic purpose of contributing to others. The work is considered as a 'vocation' and a 'calling' as a way of creating greater meaning and identity in the workplace (Moore 1992).

This is supported by Frankl's Theory of Logotherapy and Existential Analysis (Frankl 1984). Following his experience at the Nazi concentration camps during the World War II, Frankl stated that 'finding meaning' can help individuals to survive the most unfavourable conditions in life. Additionally, finding meaning is based on the individual's uniqueness, authenticity, responsibility, religious and/or secular values, creativity, love, and self-transcendence. This process may lead to the changing of attitudes towards one's own life and adopting a humane approach to oneself and others, such as, relationships between each other as a staff member and also during the delivery of care to patients.

\subsection{Community}

A sense of community in the workplace involves a connectedness with others that facilitates interactions between employees and their colleagues. This connectedness is considered as a deep relationship when the workers consider themselves as connected to each other by a relationship between one's inner self and the inner self of other people at the workplace. This level of spirituality involves the mental, emotional and spiritual connections among employees in teams or groups. Therefore, the essence of community is based on a deeper sense of connection among people, including support, freedom of expression, and genuine caring. This involves a team spirit whereby employees feel that they belong to a larger organizational community, whereby employees take care of each other as colleagues and also they take care of their customers/patients and their relatives (Arnold et al. 2005).

This impact is further outlined by Watson's Transpersonal Caring-Healing Theory (Watson 1999a) which emphasizes the caregiver's conscious intention to care, which may enhance the healing presence of the caregiver; the healing effect of medical interventions; with an impact of wholeness in the delivery of care. This process involves a nurse-patient transpersonal relationship that aims to safeguard the dignity, humanity, inner harmony, and wholeness of both the nurse and the recipient of care. This transpersonal relationship may eventually influence the attitudes of both the nurse and the patient. Consequently, transformation may occur in both the nurse and the patient, whereby both may learn from each other and relate professionally with dignity (Baldacchino 2010b). This bilateral effect is triggering various organizations to introduce 'community building exercises' to their employees as it can yield positive impact on the various relationships with colleagues, the overall organization and society.

\subsection{Alignment with the Organizational Values}

Spirituality at the workplace may be demonstrated by the employees' if they experience a strong sense of alignment of their personal values to the respective mission and purpose of their organization. 
This alignment indicates the perception that one's purpose at the workplace is larger than one's self, whereby the individual manages to perceive the importance of one's contribution to others or society. For example, caring for the patient does not only enhance the respective patient's health, but also that of the respective family that eventually may strengthen the overall strength of society. This is supported by Dalai Lama stating:

'There is no need to reform the world because:

If you reform yourself, you will reform your family;

If you reform your family, you will reform your nation;

If you reform your nation, you will reform the world'. (Gyatso 2010)

On the other hand, alignment incorporates also the values of the managers and the employees in their organization. The managers and the employees should have 'appropriate values, have a strong conscience, and are concerned about the welfare of its employees and community' (p. 430). Therefore, the organization should function with 'integrity and a purpose that is beneficial to others beyond simply making a profit' (p. 430). Alignment addresses the rationale of the employees behind their desire to work in a particular organization. This theory emphasizes the individual's goal of the worker who should seek to work in an organization with the following characteristics namely: a high sense of ethics, integrity, and make a larger contribution to the outside world while prioritizing the welfare of employees, customers, and society. Therefore, if a person does not share similar values with those of the organization, it may be challenging for that individual to work for that particular organization. While considering the various limitations of the work organizations, this theory emphasizes the importance of the organization to have a high level of commitment to their workers, customers, and society. Research indicates that personal spirituality and attitudes in care are predictors of effective care and relationships (Van Leeuwen et al. 2006; Grant et al. 2004). Nurses' own spirituality appears to be integrated within the delivery of spiritual care by demonstrating positive attitudes and respect to each other and the patients while experiencing giving to and receiving from each other including the patient (Ross et al. 2014; Formosa and Baldacchino 2010).

\section{Implications to the Education and Clinical Practice}

A person's personal spirituality was identified by research as the strongest predictor in the provision of therapeutic patient care due in part to the positive effect of this on relationships with the multidisciplinary team at the workplace (Bailey et al. 2009) and also additional personal skill in providing spiritual care to others (Van Leeuwen et al. 2006). This manifests as being in doing, whereby the nurse's personal spirituality informs their knowledge, skills, and attitudes, while supporting therapeutic relationship building and guides spiritual care delivery (Attard and Baldacchino 2014).

The nurse's role is to promote 'an environment in which the human rights, values, customs, and spiritual beliefs of the individual, family and community are respected' (International Council for Nurses ICN). The environment includes also the supportive relationships between the various members of the health care team who try to meet patients' holistic care (Baldacchino 2008). The presence of role models in the delivery of spiritual care and caring behaviours between staff members may enhance students' learning with a sense of belongingness in the clinical placements (McSherry 2006; Bradshaw 1997). Eventually, processing information by the help of role models and mentors may enhance students' spiritual self-development (Giske 2012) which helps them to give priority to patients' holistic needs (Baldacchino 2008), and may be transformational to both the patients and the caregivers (Dijoseph and Cavendish 2005). Thus spirituality at the workplace needs to be integrated within the multi-disciplinary team curricula to enhance their knowledge, skills and attitudes in their work relationships (Attard et al. 2014). Reflection by staff and students in and on delivery of care can contribute to this and may enhance self-awareness, improve patient care (Schön 1991; Gibbs 1988), and maintain positive relationships and teamwork (Scanlan et al. 2002). This is because through 
reflection staff come into contact with their inner-self, values and beliefs which may foster trustful relationships, increased priority to personal spirituality, and meeting patients' spiritual needs with dignity (Kociszewski 2003).

Reflection and awareness about personal spirituality may also be associated with holistic healing presence due to the therapeutic use of self, derived from the impact of nurturing the power within the self (Watson 1999b). Thus, the caregivers are to take the initiative to activate their being in doing and utilize their personal spirituality to enable patients, families, and staff members to find meaning and purpose in their illness and/or distress and/or their current professional care, respectively (Baldacchino 2010c; Zyblock 2010). This process may generate positive attitudes and harmonious relationships at the workplace, irrespective of their culture and religious affiliation or the absence of religion (Reed 1992). An altruistic attitude towards professional care and staff relationships may yield spiritual growth through giving and receiving (Thomas et al. 2004). This commitment may lead towards self-transformation accompanied by transformational therapeutic relationship. Thus, even the most ordinary interaction between staff or towards patients may enhance the humanization of relationships between the team members and the vulnerable patient through an increased emphasis on respecting and enhancing individual dignity that being a spiritual person fosters (Van Leeuwen and Cusveller 2004; Baldacchino 2006).

\section{Recommendations}

Some studies indicate that nurses' are drawn to nursing due to their own perception and/or experiences of the importance of compassion and caring within this profession (Tietjen 2013). However, although exploring and revisiting the importance of these attributes is becoming more important internationally, there is a dearth of research on this topic and thus this area merits further scientific research. Formal assessment of caring aptitude prior to recruitment of health caregivers, a recent addition to many UK recruitment programmes for nurses, may contribute towards the enhancement of compassionate relationships with patients and between the members of the health care team (Baldacchino and Galea 2012a; Baldacchino and Galea 2012b). This may generate a peaceful clinical environment and the development of the right attitude towards holistic care, including spiritual care (Van Loon 2005), although further research is required on the benefits of these actions.

While healthcare workers own personal spirituality was found to be beneficial for both themselves and patients in their care (Ross et al. 2015; Boero et al. 2005; Cobb 2004) further longitudinal multi-cultural research is needed particular among variant healthcare professional groups and with different religious or non-religious groups to explore the personal and organizational factors contributing towards the enhancement and maintenance of spirituality at the workplace.

However, overall, there is convincing theoretical and research evidence that developing workplace spirituality is beneficial and this is something that healthcare environments need to urgently consider. Paramount in this is the consistency with organizational values. It makes sense that if the goal of healthcare is to support and care for patients this support and care needs to be extended to individuals the workplace through the promotion of workplace spirituality. Clearly the evidence indicates that this caring for staff, by developing a spiritual workplace, where staff gain meaning, purpose and connectedness from their jobs, impacts positively on patients and their families as staff are not only happier but more attuned to the spiritual needs that these patients and families may have.

At the same time, the spiritual dimension of care needs more consideration in health. Spiritual needs of patients and families are sometimes not discussed within the multidisciplinary team (Saliba and Baldacchino 2010; Khademian and Vizeshfar 2007). This is resultant from various factors including confusion between religion and spirituality and lack of role clarity. There is also an identified lack of educational preparedness of healthcare staff, and thus a lack of confidence and competence to deliver spiritual care (Timmins et al. 2014). There is also a risk or concern about proselytizing. Thus, integration of spiritual care in the undergraduate, post-graduate educational programmes and postgraduate research programmes is of utmost importance to ameliorate sensitive patient care in 
this area. A first step in this is the determination of core competencies for spiritual care, that are now well underway in a European context through the recent acquisition of Erasmus Plus funding to support this innovation (EPICC 2017). This aforementioned project-Enhancing Nurses and Midwives' Competence in Providing Spiritual Care through Innovation, Education and Compassionate Care (EPICC) - will be crucial to the support of spiritual care in healthcare for the future by building a European network of nursing and midwifery educators, supported by other key stakeholders in order to share knowledge and skills in spiritual care. From December 2016 to August 2019, this network will review good practice and develop new resources that can be applied to nursing and midwifery education in Higher Education Institutions across Europe. The project is informed by the views of patients, students and the public; and is led by nurse educators from six universities in Malta, The Netherlands, Norway, and the UK, and will pave the way for optimal, informed spiritual care delivery in European Healthcare. Building on this the next phase of work in this area needs to consider the evidence for the importance of and ways to develop and support workplace spirituality in healthcare.

Conflicts of Interest: The author declares no conflict of interest.

\section{References}

Adamson, Carole, Elisabeth Beddoe, and Ann Davys. 2012. Building resilient practitioners: Definitions and practitioner understandings. British Journal of Social Work 32: 100-17. [CrossRef]

Arnold, John, Joanne Silvester, Fiona Patterson, Ivan Robertson, Carry Cooper, and Bernard Burnes. 2005. Work Psychology. Understanding Human Behaviour in the Workplace, 4th ed. Harlow: Pearson Education Ltd.

Ashmos, Donde P., and Denis Duchon. 2000. Spirituality at work: A conceptualization and measure. Journal of Management Inquiry 9: 134-45. [CrossRef]

Attard, Josephine, and Donia Baldacchino. 2014. The demand for competencies in Spiritual care in nursing and midwifery education: A literature review. Revista Pistis Praxis, Teologia Pastorale 6: 671-91. [CrossRef]

Attard, Josphine, Donia Baldacchino, and Liberato Camilleri. 2014. Nurses' and midwives' acquisition of competency in spiritual care: A focus on education. Nurse Education Today 34: 1460-66. [CrossRef] [PubMed]

Bailey, Maria E., Sue Moran, and Margaret Graham. 2009. Creating a spiritual tapestry: Nurses' experiences of delivering spiritual care to patients in as Irish hospice. Interventional Journal of Palliative Nursing 15: 42-48. [CrossRef] [PubMed]

Baldacchino, Donia. 2006. Nursing competencies for spiritual care. Journal of Clinical Nursing 15: 885-96. [CrossRef] [PubMed]

Baldacchino, Donia. 2008. Teaching on the spiritual dimension in care: The perceived impact on undergraduate nursing students. Nursing Education Today 28: 501-12. [CrossRef] [PubMed]

Baldacchino, Donia. 2010a. Caring in Lourdes: An innovation in students' clinical placement. British Journal of Nursing 19: 352-66. [CrossRef] [PubMed]

Baldacchino, Donia. 2010b. Spiritual Care: Being in Doing. Blata-l-Bajda: Preca Library.

Baldacchino, Donia. 2010c. Long-term causal meaning of myocardial infarction. British Journal of Nursing 19: 774-81. [CrossRef] [PubMed]

Baldacchino, Donia. 2011. Myocardial Infarction: A turning point in meaning in life over time. British Journal of Nursing 20: 107-14. [CrossRef] [PubMed]

Baldacchino, Donia. 2015. Experience teaches us! The perceived impact of heart attack on life. In The Quest for Authenticity and Human Dignity. Edited by Emanues Agius and Hector Scerri. Melita Theologica Supplementary Series 6; Tarxien: Guttenberg Press Ltd., pp. 71-92.

Baldacchino, Donia, and Peter Draper. 2001. Spiritual Coping Strategies: A Review of the Nursing Research Literature. Journal of Advanced Nursing 34: 833-41. [CrossRef] [PubMed]

Baldacchino, Donia, and Paul Galea. 2012a. Student nurses' personality traits and the nursing profession: Part I. British Journal of Nursing 21: 419-25. [CrossRef] [PubMed]

Baldacchino, Donia, and Paul Galea. 2012b. Student nurses' personality traits and the nursing profession: Part 2. British Journal of Nursing 21: 530-35. [CrossRef] [PubMed] 
Boero, Melena, M. Caviglia, R. Monteverdi, V. Braida, M. Fabello, and L. Zorzella. 2005. Spirituality of health workers: A descriptive study. International Journal of Nursing Studies 42: 915-21. [CrossRef] [PubMed]

Bradshaw, Ann. 1997. Teaching spiritual care to nurses: An alternative approach. International Journal of Palliative Nursing 3: 51-57.

Chung, Loretta Yuet Foon, Frances Kam Yuet Wong, and Moon Fai Chan. 2007. Relationship of nurses' spirituality to their understanding and practice of spiritual care. Journal of Advanced Nursing 58: 158-70. [CrossRef] [PubMed]

Cobb, Beverly J. 2004. Nursing Students' Experiences in Personal Spiritual Formation and in Provision of Spiritual Care to Patients. Ph.D. thesis, Andrews University, Berrien Springs, MI, USA.

Daniel, Jose L. 2012. A Study of the Impact of Workplace Spirituality on Employee Outcomes: A Comparison between US and Mexican Employees. Ph.D. dissertation, Texas A\&M International University, Laredo, TX, USA. Available online: https:/ / repositories.tdl.org/tamiu-ir/bitstream/handle/2152.4/18/DANIELDISSERTATION-2012.pdf?sequence=1 (accessed on 10 May 2015).

Dijoseph, Josephine, and Roberta Cavendish. 2005. Expanding the dialogue on prayer relevant to holistic care. Holistic Nursing Practice 19: 147-54. [CrossRef] [PubMed]

Duchon, Dennis, and Donde A. Plowman. 2005. Nurturing the spirit at work: Impact on work unit performance. The Leadership Quarterly 16: 807-33. [CrossRef]

EPICC. 2017. Enhancing Nurses and Midwives' Competence in Providing Spiritual Care through Innovation, Education and Compassionate Care. Available online: http:/ / epiccproject.wixsite.com/epicc (accessed on 18 September 2017).

Formosa, Antoinette, and Donia Baldacchino. 2010. The impact of spiritual care on nurses. In Spiritual Care: Being in Doing. Edited by Donia Baldacchino. Blata-1-Bajda: Preca Library, pp. 73-88.

Frankl, Viktor E. 1966. Self-transcendence as a human phenomenon. Journal of Humanistic Psychology 6: 97-106. [CrossRef]

Frankl, Victor E. 1973. The Doctor and the Soul. From Psychotherapy to Logotherapy. New York: Vintage Books.

Frankl, Viktor E. 1984. Man's Search for Meaning: An Introduction to Logotherapy, 3rd ed. New York: Simon \& Schuster.

Fry, Louis W. 2003. Toward a theory of spiritual leadership. The Leadership Quarterly 14: 693-727. [CrossRef]

Gibbons, Paul. 2015. Spirituality at Work: Definitions, Measures, Assumptions, and Validity Claims. In Handbook of Workplace Spirituality and Organizational Performance. Paper presented at the Academy of Management Meeting, Toronto, ON, Canada 6-10 August 2000; Edited by Robert A. Giacalone and Carole L. Jurkiewcz. London: Routledge.

Gibbs, Graham. 1988. Learning by Doing: A Guide to Teaching and Learning Methods. Oxford: Further Education Unit, Oxford Polytechnic.

Giske, Tove. 2012. How undergraduate nursing students learn to care for patients spiritually in clinical studies-A review of literature. Journal of Nursing Management 20: 1049-57. [CrossRef] [PubMed]

Grant, Don, Kathleen O'Neil, and Laura Stephens. 2004. Spirituality in the Workplace: New Empirical Directions in the Study of the Sacred. Sociology of Religion 65: 265-83. [CrossRef]

Gyatso, Tenzin. 2010. 14th Dalai Lama. In Spiritual Care: Being in Doing. Edited by Donia Baldacchino. Blata-l-Bajda: Preca Library.

International Council for Nurses (ICN). 2000. Code of Ethics for Nurses. Geneva: I.C.N.

Khademian, Zahra, and Fatemeh Vizeshfar. 2007. Nursing students' perceptions of the importance of caring behaviours. Journal of Advanced Nursing 61: 456-62. [CrossRef] [PubMed]

Kociszewski, Cynthia. 2003. A Phenomenological pilot study of the nurses' experience providing spiritual care. Journal of Holistic Nursing 21: 131-48. [CrossRef] [PubMed]

Koutsos, Peggy, Jenny Kornblum, and Eleanor Wertheim. 2008. Paths to interpersonal forgiveness: The roles of personality, disposition to forgive and contextual factors in predicting forgiveness. Personality and Individual Differences 44: 337-48. [CrossRef]

Levenson, Michael. R., Carolyn M. Aldwin, and Loriena Yancura. 2006. Positive emotional change; mediating effects of forgiveness and spirituality. Explore 2: 498-508. [CrossRef] [PubMed]

Liu, Caroline H., and Peter J. Robertson. 2011. Spirituality in the workplace. Journal of Management Inquiry 20: 35-50. [CrossRef]

Maslach, Christina, and Michael Leiter. 1997. The Truth about Burnout. San Francisco: Jossey-Bass. 
McKee, Margaret C., Cathy Driscoll, E. Kevin Kelloway, and Elisabeth Kelley. 2011. Exploring Linkages among transformational leadership, workplace spirituality and well-being in health care workers. Journal of Management, Spirituality and Religion 8: 233-55. [CrossRef]

McSherry, Wilfred. 2006. The principal components model: A model for advancing spirituality and spiritual care within nursing and health care practice. Journal of Clinical Nursing 15: 905-17. [PubMed]

Milliman, John, Andrew J. Czaplewski, and Jeffery Ferguson. 2003. Workplace spirituality and employee work attitudes. An exploratory empirical assessment. Journal of Organisation Change Management 16: 426-47. [CrossRef]

Mitroff, Ian I., and Elisabeth Denton. 1999. A study of spirituality in the workplace. Sloan Management Review 40: 83-93.

Montebello, Maria. 2010. Nurses' purpose and meaning in life. In Spiritual Care: Being in Doing. Edited by Donia Baldacchino. Blata-1-Bajda: Preca Library, pp. 89-102.

Moore, Thomas. 1992. Care of the Soul. New York: Harper-Collins.

Nash, Laura, and Howard Stevenson. 2004. Success that lasts. Harvard Business Review 82: 102-9. [PubMed]

Neal, Judi. 2013. Faith and Spirituality in the Workplace: Emerging Research and Practice. Handbook of Faith and Spirituality in the Workplace. London: Springer, pp. 3-18.

Overell, Stephen. 2002. The search for corporate meaning. Financial Times, September 13, 12.

Pfeffer, Jeffrey. 2003. Business and the spirit: Management practices that sustain values. In The Leadership Quarterly. Nurturing the Spirit at Work: Impact on Work Unit Performance. Edited by R. A. Giacalone and C. L. Jurkiewics. New York: M.E. Sharpe, vol. 16, pp. 29-45.

Prince-Paul, Maryjo. 2008. Relationships among communicative acts, social well-being and spiritual well-being on the quality of life at the end of life in patients with cancer enrolled in hospice. Journal of Palliative Medicine 11: 20-25. [CrossRef] [PubMed]

Reed, Pamela G. 1992. An emerging paradigm for the investigation of spirituality in nursing. Research in Nursing Health 15: 349-57. [CrossRef] [PubMed]

Roach, Simone M. 2002. The Human Act of Caring. Ottawa: Canadian Hospital Association Press.

Robinson, Simon, and Kevin D. Kendrick. 2000. Spirituality: Its relevance and purpose for clinical nursing in a new millennium. Journal of Clinical Nursing 9: 701-5.

Roger, Gill. 2014. Spirituality at work and the leadership challenge (Keynote 3). British Association for the Study of Spirituality 4: 136-48.

Ross, Linda, Rene Van Leeuwen, Donia Baldacchino, Tove Giske, Wilfred McSherry, Aru Narayanasamy, Carmel Downes, Paul Jarvis, and Annemiek Schep-Akkerman. 2014. Student nurses' perceptions of spirituality and competence in delivering spiritual care: A European Pilot Study. Nurse Education Today 34: 697-702. [CrossRef] [PubMed]

Ross, Linda, Tove Giske, Rene Van Leeuwen, Donia Baldacchino, Wilfred McSherry, Aru Narayanasamy,

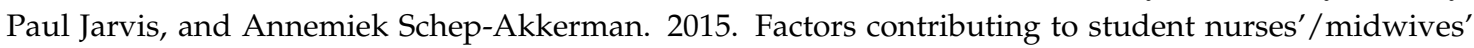
perceived competency in spiritual care. Nurse Education Today 36: 445-51. [CrossRef] [PubMed]

Sadeghifar, Jamil, Mohammed Bahadori, Donia Baldacchino, Mehdi Radaabadi, and Mehdi Jafari. 2013. Relationship between Career Motivation and Perceived Spiritual Leadership in Health Professional Educators: A Correlational Study in Iran. Global Journal of Health Science 6: 1-10. [CrossRef] [PubMed]

Saliba, Theresa, and Donia Baldacchino. 2010. Spiritual care: Perceptions of health care professionals working with clients with dementia. In Spiritual Care: Being in Doing. Edited by Donia Baldacchino. Blata-1-Bajda: Preca Library, pp. 57-72.

Scanlan, Judith M., Dean W. Care, and Sonia Udod. 2002. Unravelling the unknowns of reflection in classroom teaching. Journal of Advanced Nursing 38: 136-43. [CrossRef] [PubMed]

Schön, Donald A. 1991. The Reflective Practitioner, 2nd ed. San Francisco: Jossey Bass.

Solutions, Kaizen. 2015. Spirit at Work. Available online: http://kaizensolutions.or/saw.html (accessed on 10 May 2015).

Tanyi, Ruth A. 2002. Towards clarification of the meaning of spirituality. Journal of Advanced Nursing 39: 500-9. [CrossRef] [PubMed]

Thomas, Joan D., Linda P. Finch, Savina O. Schoenhofer, and Ann Green. 2004. The caring relationships created by nurse practitioners and the ones nursed: Implications for Practice. Topics in Advanced Practice Nursing eJournal 4: 1-14. Available online: http:/ / www.medscape.com/viewarticle/496420 (accessed on 19 April 2010). 
Tietjen, Susanne. 2013. It's Not Just a Nursing Career, It's a Calling. Available online: http://www. nursingworldnigeria.com/2013/02/it-rsquo-s-not-just-a-nursing-career-it-rsquo-s-a-calling (accessed on 28 October 2013).

Timmins, Fiona, Freda Neill, Mary Quinn-Griffin, John Kelly, and Eden DeLa Cruz. 2014. Spiritual Dimensions of Care: Developing an Educational Package for Nurses in the Republic of Ireland. Holistic Nursing Practice 282: 106-23. [CrossRef] [PubMed]

Torskenes, Kristina B., Donia Baldacchino, Tracy Baldacchino, Josette Borg, Marica Falzon, and Mary Kalfoss. 2013. Nurses' and informal caregivers' definition of spirituality from the Christian perspective: A comparative study between Malta and Norway. Journal of Nursing Management 23: 39-53. [CrossRef] [PubMed]

Van Leeuwen, Rene, and Barth Cusveller. 2004. Nursing competencies for spiritual care. Journal of Advanced Nursing 48: 234-46. [CrossRef] [PubMed]

Van Leeuwen, Rene, Lucas Tiesinga, Doeke Post, and Henk Jochemsen. 2006. Spiritual care: Implications for nurses' professional responsibility. Journal of Clinical Nursing 15: 875-84. [CrossRef] [PubMed]

Van Loon, Antonia M. 2005. Commentary on Fawcett T, Noble A (2004) The challenge of spiritual care in a multi-faith society experienced as a Christian nurse. Journal of Clinical Nursing 13: 136-42.

Watson, Jean. 1999a. Postmodern Nursing and Beyond. London: Churchill Livingstone.

Watson, Jean. 1999b. Theory of Human Caring. Available online: http://watsoncaringscience.org/images / features/library/THEORY\%20OF\%20HUMAN\%20CARING_Website.pdf (accessed on 18 September 2017).

World Health Organisation. 1998. WHOQOL and Spirituality, Religiousness and Personal Beliefs. Report on WHO Consultation. Geneva: W.H.O.

Zyblock, Dee Marie. 2010. Nursing presence in contemporary nursing practice. Nursing Forum 45: 120-24. [CrossRef] [PubMed]

(C) 2017 by the author. Licensee MDPI, Basel, Switzerland. This article is an open access article distributed under the terms and conditions of the Creative Commons Attribution (CC BY) license (http:/ / creativecommons.org/licenses/by/4.0/). 